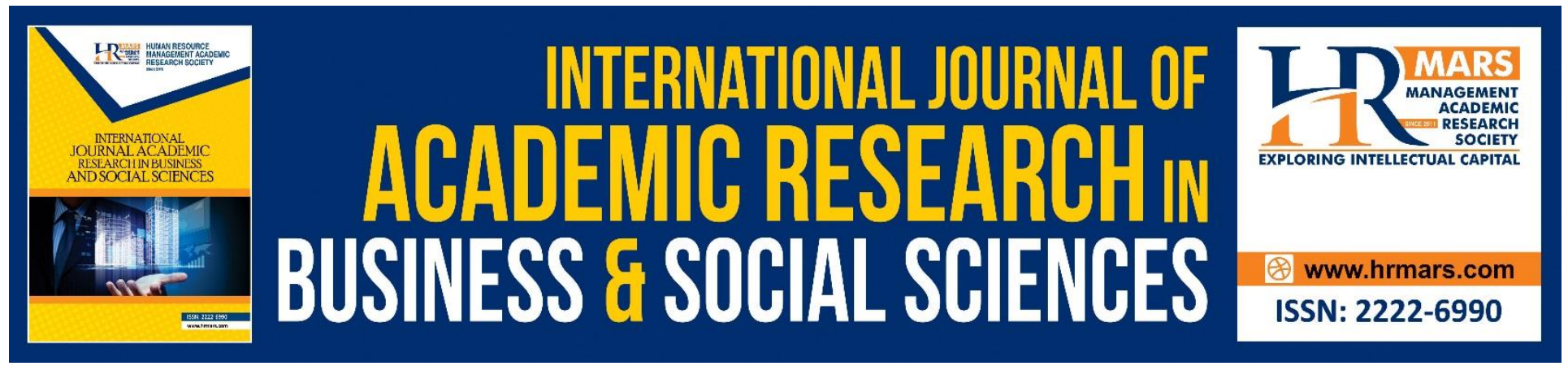

\title{
Impact of Emotional Intelligence on Job Performance Mediating Role of Self-Leadership
}

Shama Noreen, Sadia Munir, Bassam Zaheer, Mohsan Idris

To Link this Article: http://dx.doi.org/10.6007/IJARBSS/v8-i11/4883

DOI: $10.6007 /$ IJARBSS/v8-i11/4883

Received: 26 Sept 2018, Revised: 13 Oct 2018, Accepted: 29 Oct 2018

Published Online: 05 Nov 2018

In-Text Citation: (Noreen, Munir, Zaheer, \& Idris, 2018)

To Cite this Article: Noreen, S., Munir, S., Zaheer, B., \& Idris, M. (2018). Impact of Emotional Intelligence on Job Performance Mediating Role of Self-Leadership. International Journal of Academic Research in Business and Social Sciences, 8(11), 44-54.

Copyright: (C) 2018 The Author(s)

Published by Human Resource Management Academic Research Society (www.hrmars.com)

This article is published under the Creative Commons Attribution (CC BY 4.0) license. Anyone may reproduce, distribute, translate and create derivative works of this article (for both commercial and non-commercial purposes), subject to full attribution to the original publication and authors. The full terms of this license may be seen at: http://creativecommons.org/licences/by/4.0/legalcode

Vol. 8, No. 11, 2018, Pg. 44 - 54

Full Terms \& Conditions of access and use can be found at http://hrmars.com/index.php/pages/detail/publication-ethics 


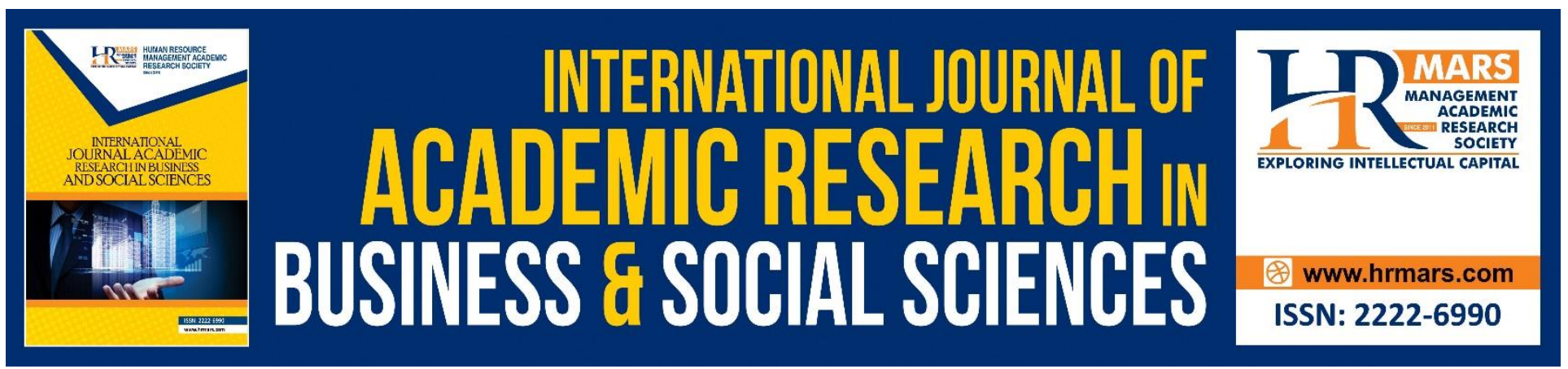

\title{
Impact of Emotional Intelligence on Job Performance Mediating Role of Self-Leadership
}

\author{
Shama Noreen \\ University of Gujrat, Sub-campus Narowal \\ Sadia Munir \\ University of Gujrat, Sub-campus Narowal \\ Bassam Zaheer \\ University of Gujrat, Sub-campus Narowal \\ Mohsan Idris \\ University of Gujrat, Sub- campus Narowal
}

\begin{abstract}
Purpose: The basic aim of this study is to investigate the impact of emotional intelligence on teacher's job performance through self-leadership among the various universities of Pakistan.

Design/methodology/approach: The data collected to analyze the relationship between emotional intelligence and teacher's job performance of different universities teacher's by asking questions directly to the teachers of the university. Three hundred respondents taken under sample space belonging to various universities on the stratified basis to show uniformity and impartiality of this research. Furthermore, the quantitative and statistical approach used to examine the results and compile in a meaningful manner.

Findings: The finding of this study showed that emotional intelligence has a positive and significant relationship with teacher's job performance and self-leadership among the teachers emotional intelligence significantly mediates the relationships between emotional intelligence and teacher's job performance.

Research restraints: This study limited in various universities of Pakistan in Punjab and only teachers who have 17 to 18 grade were included in sample space.

Originality/value: This study show the emotional intelligence increase teacher's job performance on work place.
\end{abstract}

Keywords: "Emotional intelligence" self-leadership" teacher's job performance" 
INTERNATIONAL JOURNAL OF ACADEMIC RESEARCH IN BUSINESS AND SOCIAL SCIENCES

Vol. 8, No. 11, Nov, 2018, E-ISSN: 2222-6990 @ 2018 HRMARS

\section{Introduction}

The main objective of this study is to show the emotional intelligence impact on teacher's job performance and self-leadership as a mediator. Teachers are biggest stakeholder of any nation. Teachers build nation and make nation. Today certain challenges are prevailing in educational sector due to poor academic performance. The reason of this problem is non-serious attitude of students and heavy workload on teachers such issues are biggest challenges of teachers to cope of this problem. Today's world the role of teachers has become more complex and diverse (Williams, Cheung, \& Choi, 2000). Teacher's responsibility to educate future generation and shape the personality of students. Social and organizational pressure to create emotional disturbance on teacher's performance. If teachers put effort to develop nation through control emotions then this challenges of poor academic performance easily cop. In this regard, emotional intelligence plays significant role in teacher's job performance. In past much more studies has focused on emotional intelligence. The first argued gave Charles Darwin in the time of portrayed when emotional expression essential for survival. With the passage of time developed different school of thought, that human behavior does not explain the person's competencies rather emotional expression are essential for to predict the future success. Such competencies that allow people to make their own way in a complex world by success-fully dealing with people and the environment have come to be refer to as emotional intelligence. The two school of thought the emotional intelligence one skill based model proposed by(Brenner \& Salovey, 1997) and some other approaches were propose by Bar-on (1997). Emotional intelligence enhance organizational performance and creativity and increase leadership skill. (Stewart, Courtright, \& Manz, 2011) proposed self-leadership through which individual target their cognition and actions towards desired outcomes and typically comprises three categories behavior-focused natural-rewards and constructive-thought-pattern strategies (Neck \& Manz, 1996). An individual men and women control their emotion and thinking. Emotional intelligence and self-leadership were effected person interest and ability towards job performance. Previous research has only focused on data collection organizational sector and different industry it also showed a positive response on emotional intelligence with job performance. However, educational sector highly demanding and attention paying any mistake in this sector loss any nation and hundreds of nation child. So taking these people into our sample space for asking about emotional intelligence impact teachers job performance. This study specifically puts emphasize on the various universities of Punjab Pakistan and further research can be conducted by adding different universities of other provinces of Pakistan and international universities of other countries. Selected various universities and teachers reposed were impact the result of our research. The educational structure of this research is as follow: previous work done on evaluating emotional intelligence impact teacher's job performance by mediating self-leadership in section-2 determinants of emotional intelligence and methodology are show in section-3. Section-4 explain the results and discussions. Section-5 presents the conclusion and recommendations additions to this research for futures up gradation.

\section{LITERATURE REVIEW}

In this article portion, we reviewed different kind of literature regarding emotional intelligence and its impact on teacher's job performance by mediating self-leadership. The basic purpose of this 
portion is to check that how many studies on emotional intelligence and its impact on teacher's job performance has already done in past year. Underlying literature shows different studies on emotional intelligence, teacher's job performance, self-leadership. Education play important role in the success of any nation and reshape human nature in every discipline. Education developed mentally and physically of human's ability and skill. For the successful teaching it was just not required the subject knowledge but it also needed the effective skill. This study declared those skills as emotional intelligence(Goleman, 1995). Teachers are the backbone of the educational institution, without teachers, these institutes were consider the body without soul. In the previous research discovered that emotional intelligence strong correlation on teacher's job performance and work outcome. (Mayer \& Cobb 2000) emotional intelligence effected teacher's job performance and interpersonal abilities who influenced work related outcomes of any individual(Fox \& Spector, 2000) argued that traits base emotional intelligence positively affected individual performance.(Day \& Carroll, 2004) this study explored that emotional intelligence and job performance in term of decision making that better results achieved through emotional performance. The person who have highly emotional intelligence they capable control the other emotions.(Guo, Dai, \& Yang, 2016) job performance significantly affected organizational goal and objective. The awareness of one's own and others emotions individuals to establish sound interpersonal relationship with others (Mayer, Caruso, \& Salovey, 1999). People with this ability therefore, should be able to recognize and understand what their emotions are and know how to apply them in improving their relationships with others (Mayer et al., 1999). Such improved relationships may in turn lead to improve job performance. In addition, people with high emotional awareness may be more successful in dealing with uncertainty within their environment (Bar-On, 1997) Mathews Et all, 2002). That ability has been founded to significant effects in successfully managing stress (Shmueli Gabel, Dolan, \& Luc Cerdin, 2005). (Shmueli Gabel et al., 2005) suggested that this ability might allow individuals to better control their personal feelings in dealing with stress, because of conflict issues. High levels of El have also been show to affect individual communication skills (Conte, 2005). In this case, individuals regard their own emotions and the emotions of others as a basis to determine which styles are appropriate in communicating with others (Mehta \& Singh, 2009) "thus creating a positive occupational environment" .

Empirically, scholars have supported the positive impacts of El on teacher's job performance. A metaanalysis by (Van Rooy \& Viswesvaran, 2004) found that El was a key factor in overall job performance. Based on above discussions, the following hypothecs has developed.

H1: Emotional intelligence effects positively and significantly on teacher performance.

The main purpose of the present study is to indicate that the improved emotional intelligence leads towards the better teacher's job performance. The first hypothesis was emotional self-awareness has significant and positive impact with the teacher's job performance and it is accepted statistically as well. Emotional intelligence is the capacity to observe and express feelings and emotions, and dealing them in an effective way that would increase the chance to enhance the personal development (Corcoran \& Tormey, 2012).

Self-leadership was first developed and proposed by Manz as an extension of self-management theory. Over the past two decades, the self-leadership concept extensively written about as 
evidenced by the large number of practitioner-oriented self-leadership books and articles on the subject.

H2: Emotional intelligence effects positively and significantly on self-leadership.

Self-leadership, introduced by Manz (1986) and Manz and Sims (1980) as the regulation of one's thoughts and behaviors, now has been studied for over 30 years (Stewart et al., 2011) This paper work on self-leadership and job performance. The work on self-leadership 30 years ago, (Manz \& Stewart et all) self-leadership is a distinctive factor between theoretically construct and debate around construct. This paper investigates professional leadership experience through bi-factor structure equation modeling which used to two motivational construct. This paper predicts individual job performance and leader-ship behavior who influence individual performance and used bi-factor model. This paper based on self-leadership and self-rating who eliminate what factor are influence self-leadership. This paper leadership experience closely related to self-leadership and concerning the ability to increase the job performance.

H3: Self-leadership effects positively and significantly on teacher performance.

Self-leadership was first developed and proposed by Manz $(1983 ; 1986)$ as an extension of selfmanagement theory. Over the past two decades, the self-leadership concept has been extensively written about as evidenced by the large number of practitioner oriented self-leadership books and articles on the subject. Self-leadership refers to a comprehensive self-perspective that concern leading oneself towards performance of naturally motivating tasks as well as managing oneself to do work that must be done but is not naturally motivating. Self-leadership has often served as a starting point for training interventions seeking to enhance employee's performance, attendance rate and wellbeing.

H4: Self-leadership mediates the relationship between emotional intelligence and teacher performance.

The previous study indicates that strong correlation between emotional intelligence and teacher's performance and self-leadership provide the significant results according to my present study. Emotional intelligence have a positive effect on job performance.

\section{Theoretical model}

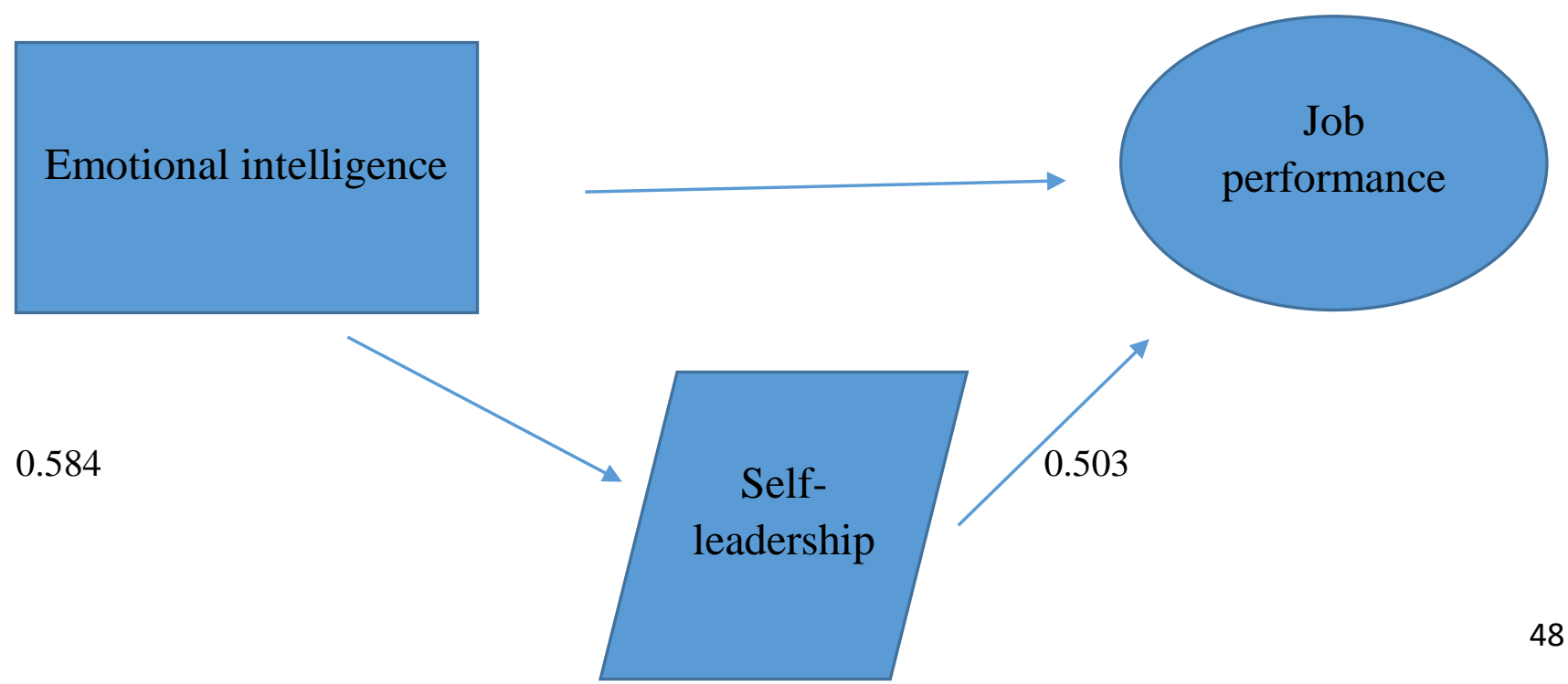


INTERNATIONAL JOURNAL OF ACADEMIC RESEARCH IN BUSINESS AND SOCIAL SCIENCES

Vol. 8, No. 11, Nov, 2018, E-ISSN: 2222-6990 @ 2018 HRMARS

\section{Research hypothesis}

From the above framework, following hypotheses made.

H1: Emotional intelligence effects positively and significantly on teacher performance.

H2: Emotional intelligence effects positively and significantly on self-leadership.

H3: Self-leadership effects positively and significantly on teacher performance.

H4: Self-leadership mediates the relationship between emotional intelligence and teacher performance.

\section{Methodology}

For this study, researcher used the survey method for the collection of data. The questionnaire were designed and data were collected from university teachers. Convenient sampling technique is used. After the collection the data, data was filtered from typo errors and missing values. Researcher used the regression analysis for the measurement of relationship of emotional intelligence impact on teacher's performance. After the analysis, the conclusion remarks and recommendations are given. Methodology plays its important role in conducting any research. It is helpful to find the relationship of dependent variable with independent variables. It can provide a comprehensive understanding of the different aspect of emotional intelligence with reference to teachers' performance. In order to analyzing the emotional intelligence and job performance among different universities by mediating self-leadership the secondary data filling the questionnaires 17 to 18 grade teachers of various university. Emotional intelligence positively influence teacher's performance and self-leadership strongly influence both. Lack of emotional

Intelligence create frustration and poor performance. Every employee of different university that will mapped to the emotional intelligence and teacher's job performance asked total of 52 question.

\section{Data Analysis}

Using stratified sampling the basic aim is to investigate the emotional intelligence impact teacher's job performance. For collecting dada, questionnaires were used; the target was to get 300 questionnaires solved by universities teachers from which 185 questionnaires were received. Data analysis part started will be afterwards. Teachers filling the questionnaires were grade 17 to 18 . A quantitative method was use for data collection. Data was collect in the form of questionnaires from different universities. The scale of (Baron \& Kenny) model was used in order to measure the emotional intelligence and on influence the teacher's job performance. This based upon 29 questionnaires of emotional intelligence 9 question of self-leadership and 14 questionnaire of teacher's performance. This was based upon five point marking scheme named Likert scale, where strongly agree carries 1 marks and agree carries 2 mark neutral carries mark 3 disagree carries mark 4 and strongly disagree carries mark 5 . The data obtained will be in the form of questionnaires and these questionnaires were collect from the universities one hundred eighty five questionnaires were obtain in the form of hardcopy that the teachers were asked to return after filling it. Statistical analysis software SPSS was used for analyzing data after collecting a sufficient number of responses from the teacher's. Correlation and regression will be use to interpret the results. The total 106 male and 194 female which given frequency $35.3 \%$ and $64.7 \%$. The age factor less than 25 year 26 to 30 , 
INTERNATIONAL JOURNAL OF ACADEMIC RESEARCH IN BUSINESS AND SOCIAL SCIENCES Vol. 8, No. 11, Nov, 2018, E-ISSN: 2222-6990 @ 2018 HRMARS

31 to 35,36 to 40 year and above 40 year whose work experience affect our research result. Our study present in the form of real time data collection and shown positively effect on teachers job performance.

\section{Respondent Profile}

\begin{tabular}{|l|l|l|l|}
\hline & Category & Frequency & \% \\
\hline Gender & Male & 106 & 35.3 \\
\hline & Female & 194 & 64.7 \\
\hline & & & \\
\hline Age & less than 25year & 114 & 38.0 \\
\hline & $26-30$ year & 123 & 41.0 \\
\hline & $31-35$ year & 47 & 15.7 \\
\hline & $36-40$ year & 6 & 2.0 \\
\hline & above 40 & 10 & 3.3 \\
\hline & & & \\
\hline Work experience & Less than 2 year & 114 & 38.0 \\
\hline & 2-4 year & 78 & 26.0 \\
\hline & 4-6 year & 64 & 21.3 \\
\hline & 6-8 year & 30 & 10.0 \\
\hline & More than 8 year & 14 & 4.7 \\
\hline
\end{tabular}

\section{Descriptive analyses}

\begin{tabular}{|l|l|l|l|l|l|l|}
\hline Variables & Mean & SD & Cronbach a & $\mathbf{1}$ & $\mathbf{2}$ & $\mathbf{3}$ \\
\hline EI & 2.0408 & .37667 & .843 & 1 & & \\
\hline SL & 1.9289 & .50133 & .766 & .584 & 1 & \\
\hline TP & 1.7933 & .45433 & .823 & .494 & .503 & 1 \\
\hline
\end{tabular}

\section{Hypotheses Testing}

Emotional intelligence positively and significantly effect on teacher performance $(B=.494 ; P=.000)$. Emotional intelligence positively and significantly effect on self-leadership $(B=.584 ; P=.000)$. Selfleadership positively and significantly effect on teacher performance $(B=.503 ; P=.000)$. Our study used Baron \& kenny model to test mediation between emotional intelligence and teacher performance according to this model the $1^{\text {st }}$ step is to check the relation between independent and dependent and $2^{\text {nd }}$ step is to check the relationship between independent and mediator(these results must be significant). In $3^{\text {rd }}$ step regressing the dependent variable on the independent variable. According to $3^{\text {rd }}$ step if independent shows significant on mediator; the mediator shows significant on dependent and independent shows no significant on dependent then there is full mediation. 


\section{Discussion}

In our research, statistical technique that we used was linear regression to inspect the conjectured relationship between variable. Table $2^{\text {nd }}$ characterized for checking the hypothesized relationship of the standardized statistical values of beta. As in our proposed hypothesis, there is a positive relationship between emotional intelligence and teacher's job performance and significant relationship self-leadership with both variables. The first hypothesis Emotional intelligence positively and significantly effect on teacher performance $(B=.494 ; P=.000)$. The second hypothesis testing Emotional intelligence positively and significantly effect on self-leadership $(B=.584 ; P=.000)$. The third hypothesis Self-leadership positively and significantly effect on teacher performance $(B=.503$; $\mathrm{P}=.000$ ). Our proposed hypothesis results significant and shown positively affect with each other. The present study add a value addition in the "(Goleman, 1995)" which indicate that control the thinking of others. The main purpose of the present study is to indicate that emotional intelligence lead better performance of teacher's performance and emotional intelligent teacher's performance will be increase and provide better results.

\section{Conclusion}

After analyzing and modelling the results, we came to point that emotional intelligence play important role in educational sector on teacher's job performance. Those teachers who have strong emotional intelligence are more likely to perform well in work. Emotional intelligence should be a universal construct across cultures. Emotional intelligence enhance work performance and this study demonstrates that teaching profession require certain level of emotional intelligence. In this regard, designing appropriate training programs to improve teacher's emotional intelligence is worthwhile. Teachers have a significant role in society as they interact with the students to transfer their knowledge to them. For transferring knowledge in a proper way they should be emotionally, stable. Teachers should have effective skills physically as well as mentally, which named as emotional intelligence. Emotional intelligence is helpful for teacher's performance, as it would guide them to communicate clearly, lead others in a proper way, which creates productive interaction at work as well as personal life.

\section{Recommendations}

This study is limited in various university of Punjab only the teachers who have 17 to 18 grade were included in sample space. This can be increased to worldwide and different organizational sector of Pakistan. Furthermore this research in only limited to various universities of Punjab and it should be cove big organization like international universities, banks, customers and consumers market, staffing firm and research center. The finding of this study showed that emotional intelligence has a significant and positive relationship with teacher's job performance and self-leadership among the teachers emotional intelligence significantly mediates the relationship between emotional intelligence and teacher's job performance.

\section{Reference}

Bar-On, R. (1997). BarOn emotional quotient inventory: Multi-Health Systems. 
INTERNATIONAL JOURNAL OF ACADEMIC RESEARCH IN BUSINESS AND SOCIAL SCIENCES Vol. 8, No. 11, Nov, 2018, E-ISSN: 2222-6990 (C) 2018 HRMARS

Brenner, E., \& Salovey, P. (1997). Emotional development and emotional intelligence: Educational implications. In: New York: Basic Books.

Conte, J. M. (2005). A review and critique of emotional intelligence measures. Journal of Organizational Behavior, 26(4), 433-440.

Corcoran, R. P., \& Tormey, R. (2012). Assessing emotional intelligence and its impact in caring professions: The value of a mixed-methods approach in emotional intelligence work with teachers. In Emotional Intelligence-New Perspectives and Applications: InTech.

Day, A. L., \& Carroll, S. A. (2004). Using an ability-based measure of emotional intelligence to predict individual performance, group performance, and group citizenship behaviours. Personality and Individual differences, 36(6), 1443-1458.

Fox, S., \& Spector, P. E. (2000). Relations of emotional intelligence, practical intelligence, general intelligence, and trait affectivity with interview outcomes: it's not all just 'G'. Journal of Organizational Behavior: The International Journal of Industrial, Occupational and Organizational Psychology and Behavior, 21(2), 203-220.

Goleman, D. (1995). Emotional intelligence: Why it can matter more than IQ. In: New York: Bantam Books.

Guo, W., Dai, R., \& Yang, J. (2016). The effect of leadership task behavior and relational behavior on job performance: investigating the moderating role of work alienation. Journal of Service Science and Management, 9(02), 97.

Mayer, J. D., Caruso, D. R., \& Salovey, P. (1999). Emotional intelligence meets traditional standards for an intelligence. Intelligence, 27(4), 267-298.

Mehta, S., \& Singh, N. (2009). A Review paper on emotional intelligence: Models and relationship with other constructs. International Journal of Management \& Information Technology, 4(3), 342-353.

Neck, C. P., \& Manz, C. C. (1996). Thought self-leadership: The impact of mental strategies training on employee cognition, behavior, and affect. Journal of Organizational Behavior, 17(5), 445467.

Shmueli Gabel, R., Dolan, S. L., \& Luc Cerdin, J. (2005). Emotional intelligence as predictor of cultural adjustment for success in global assignments. Career Development International, 10(5), 375395. 
Stewart, G. L., Courtright, S. H., \& Manz, C. C. (2011). Self-leadership: A multilevel review. Journal of Management, 37(1), 185-222.

Van Rooy, D. L., \& Viswesvaran, C. (2004). Emotional intelligence: A meta-analytic investigation of predictive validity and nomological net. Journal of vocational Behavior, 65(1), 71-95.

Williams, K. D., Cheung, C. K., \& Choi, W. (2000). Cyberostracism: effects of being ignored over the Internet. Journal of personality and social psychology, 79(5), 748.

\section{Corresponding Author:}

Sadia Munir

Email: sadiamunir770@gmail.com 